\title{
Absorbable versus Non-Absorbable Sutures in Paediatric Facial Trauma - A Cosmetic Assessment
}

\author{
Pinki Pargal ${ }^{1}$, \\ ${ }^{1}$ Department of Plastic Surgery, Christian Medical College \& Hospital, Ludhiana, Punjab, India
}

\section{ABSTRACT}

\section{BACKGROUND}

Paediatric age group is most vulnerable to trauma. Children often suffer facial injuries. Though many topical skin adhesives and strips are available in the market which have given excellent cosmetic results, deeper injuries especially along the lines of high tension need suturing both with buried and skin sutures. Different variety of sutures are available in the market which are used as per the choice of the surgeon. Children are more apprehensive when it comes to suture removal. So use of absorbable sutures in place of non-absorbable sutures in skin can save the children from this fear factor.

\section{METHODS}

A prospective study was done in the department of plastic surgery from May 2012 to Dec. 2013 with an objective of studying the outcome of plain catgut suture as skin sutures versus non-absorbable skin suture Nylon in facial trauma in the paediatric age group. Chromic catgut was used as buried suture in both groups. All the patients presenting in emergency department with facial trauma with age 10 years or less were included in the study. Skin sutures, where needed removal, were removed on $5^{\text {th }}$ post-operative day followed by follow up on $7^{\text {th }}$ post-operative day, $3^{\text {rd }}$ month and $8^{\text {th }}$ month during which cosmetic assessment of scar was done. 25 patients who presented first in emergency and fulfilled the study criteria were sutured with 5 - 0 chromic catgut buried sutures and skin suture used was 6 - 0 Nylon and this group was labelled group A. Next 25 patients who presented in emergency for suturing were sutured with 5 - 0 chromic catgut as buried and plain catgut as skin suture. This group was labelled as Group B. Cosmetic outcome was assessed on $7^{\text {th }}$ post-operative day, $3^{\text {rd }}$ month and $8^{\text {th }}$ month by using Beusang E cosmetic scar assessment scale based on two parameters which included colour and texture of scar. ${ }^{1}$ Statistical analysis was done with continuous variables expressed as Mean \pm S.D. and categorical variables were expressed as count (percentage). Chi-square was used to compare the categorical variables between groups or Fisher exact test was used.

\section{RESULTS}

On $7^{\text {th }}$ post-operative day follow up, out of 50 patients, 25 patients (50\%) in whom nylon was used as skin suture, 4 patients (16\%) had mismatch of colour. All scars were smooth in texture. In rest 25 patients (50 \%) in whom plain catgut was used as a skin suture, 1 ( $4 \%$ ) patient had mismatch of the colour. None of the patients had frank pus in both groups \& hypertrophic scar was seen in one patient. On $3^{\text {rd }}$ month follow up, Group A patients with nylon as skin suture, 1 (4\%) patient showed hypertrophic scar whereas in Group B (8\%) patients had hypertrophic scar. On $8^{\text {th }}$ month follow up, both group A \& B had colour mismatch of $12 \%$ with firm texture of scar in $8 \%$ patients.

\section{CONCLUSIONS}

There is no long-term differences in cosmetic outcomes and complication rates between absorbable catgut suture and commonly used nylon sutures in the repair of facial trauma in paediatric age groups. So, absorbable sutures are acceptable alternative to non-absorbable suture especially in paediatric age group, keeping in mind their apprehensive nature and fear of suture removal.

\section{KEY WORDS}

Absorbable Suture, Plain Catgut, Buried Suture, Chromic Catgut, Non-Absorbable Suture, Nylon, Facial Trauma, Suturing, Paediatric Age Group
Corresponding Author:

Dr. Pinki Pargal.

Gateway Terrace 10,

Opp. CMC Hospital, Doctor's Colony,

Ludhiana, Pinjab, India.

E-mail: pinkipargal@gmail.com

DOI: $10.14260 /$ jemds/2020/566

How to Cite This Article:

Pargal P. Absorbable versus nonabsorbable sutures in paediatric facial trauma - a cosmetic assessment. J Evolution Med Dent Sci 2020;9(36):2601-2604, DOI: 10.14260/jemds/2020/566

Submission 02-06-2020,

Peer Review 26-07-2020,

Acceptance 03-08-2020,

Published 07-09-2020.

Copyright (C) 2020 JEMDS. This is an open access article distributed under Creative Commons Attribution License [Attribution 4.0 International (CC BY 4.0)] 


\section{BACKGROUND}

Egyptian scrolls described the art of suturing wounds as early as $3500 \mathrm{BC}$. Suture materials used in the past centuries consisted of horsehair, animal tendons, vegetable fibers and human hair. $^{3}$ since then with advancement of modern techniques in processing of suture material resulted in wide variety of suture material in the market which included both absorbable and non - absorbable sutures. Trauma anywhere in the body needs suturing especially suturing of the outermost layer of the skin with non-absorbable sutures which needs removal once wound is healed.

Ideally non-absorbable Nylon suture is used for skin closure. ${ }^{4}$ However in past few decades different approaches have evolved where the skin suturing is replaced by Topical skin adhesives like butyl cyanoacrylate and octyl cyanoacrylate which are easy to apply and gave good results in superficial wounds. ${ }^{5}$ Adhesive strips have also come in market. ${ }^{6}$ All the superficial injuries in any part of the body gave good results with these techniques but deeper wounds always required suturing Skin suturing is the only treatment in such cases, in addition to skin sutures buried sutures played important to obliterate the dead space. ${ }^{7}$

Various sutures used for skin suturing are available in market, they are either absorbable or non-absorbable. Various studies available have shown no significant differences with respect to wound appearance and infection rates between absorbable and non - absorbable sutures ${ }^{8}$. Among the nonabsorbable suture most often used is Nylon. Its sterile, synthetic monofilament which provide good tensile strength and low tissue reactivity, dyed black or green for better visibility Non absorbable sutures on the face need removal between 4 and 6 days. Catgut suture available as plain catgut or chromic catgut. It's derived from processed sheep or cattle intestines and was first described for use in suturing in 1870s. It's degraded by proteolytic enzymes in the tissues and when pretreated with heat produces a fast absorbing material that dissolves between 3 to 10 days ${ }^{9}$.

These sutures when used needs no removal, only unraveled suture were removed keeping in mind this quality of suture this can be used in skin suturing of paediatric age group. Children are apprehensive of pain associated with suture removal, especially if they have unpleasant memories of their initial suturing. This suture if used lessens the number of hospital visits and costs associated with follow up can be minimized. The present study was done to compare the cosmetic results of absorbable suture Plain catgut with nonabsorbable Nylon suture and also to compare complications rates in these suture material. So that in future absorbable suture can be used in paediatric age group if its long-term cosmetic results were comparable with non-absorbable suture.

\section{Objectives}

To compare the long-term cosmetic outcome of Absorbable Versus Non - Absorbable Suture in Paediatric Facial Trauma \& Comparison of complication rates.

\section{METHODS}

A prospective study was done in the department of plastic surgery from May 2012 to Dec 2013 after obtaining institutional ethic committee clearance. All the patients presenting in emergency with facial trauma with age 10 year or less were included in study. Exclusion criteria included 1) all those facial injuries presented late, that is after 8 hours of trauma. 2) Grossly contaminated wounds. 3) Wounds with associated abrasions 4) all superficial wounds where topical adhesives or strips can be applied. Out of the 80 patients who presented for facial suturing during the study period, only 50 patients were enrolled as they fulfilled the criteria. Informed consent was taken from the patient parent / guardian. Once agreed a detailed history which included demographic profile and mode of injury were noted.

A photographic record was maintained in follow up period with same digital camera with same settings. Non - absorbable skin sutures when used removal was done on on $5^{\text {th }}$ post operative day followed by follow up on $7^{\text {th }}$ post - operative day, 3rd month and $8^{\text {th }}$ month during which cosmetic assessment of scar was done. Randomization of the patients was done by dividing patients into two groups. 25 patients who presented first in emergency and fulfilled the study criteria were sutured with 5 - 0 or 6 - 0 Nylon skin sutures and this group was labelled group A. Next 25 patients who presented in emergency with facial injury 5-0 plain catgut was used as skin suture and this group was labelled as Group B. Cosmetic outcome was again assessed on $7^{\text {th }}$ post -operative period, $3^{\text {rd }}$ month and $8^{\text {th }}$ month. Cosmetic Assessment of scar was done using Beusang E cosmetic scar assessment scale based on two parameters which included Colour and texture of scar. In Colour it was noted whether the scar matched the surrounding skin or there was any mismatch. Similarly in texture it was noted whether scar site was smooth or firm.

Presence or absence of wound infection was noted taking four parameters into account which included presence or absence of Redness, Serosanguinous collection, frank pus, Oedema, Presence of hypertrophic scar during the follow up visit was also noted. In case of patients where plain catgut was used as skin suture, premature unravelling of sutures was also noted. Simple interrupted suturing technique using a cutting needle was used in both groups. Injuries on the face which had deep wounds, requiring multilayer closure 5 - 0 chromic catgut was used as buried suture. In both the groups Steristrips were used after suturing to optimize wound approximation ${ }^{9}$ Patients were discharged with standardized wound care instructions.

\section{Statistical Analysis}

In the descriptive analysis, continuous variables were expressed as Mean \pm S.D. and categorical variables were expressed as count (percentage). Chi-square was used to compare the categorical variables between groups or Fisher exact test was used when expected count was $<5$. Independent t-test was used to compare continuous variables between two groups. The significance level was set at $\mathrm{p}<0.05$. All statistical analysis was performed using SPSS, version 21.0. Armonk, NY: IBM corp. 


\section{RESULTS}

A total of 50 children was enrolled in the study in the age group of 0 - 10 years. Male: female ratio was 3:1. The Mean (SD) age of patients in Nylon group 4.4 (2.1) years was comparable with Catgut group 3.9 (2.5) years, $\mathrm{p}=0.442$. The cause of injury was fall for $28(56 \%)$ of the patients and RTA for 22 (44\%) of the patients.

On $7^{\text {th }}$ Post - Operative Day follow up, Out of 50 patients, 25 patients (50\%) in whom nylon was used as skin suture, 4 patients (16\%) had mismatch of colour, $3(12 \%)$ patients had redness of the scar, 2 (8\%) patients had serosanguinous collection, $3(12 \%)$ patients had oedema of the scar. None of the patients had frank pus or hypertrophic scar. All the scars were smooth in texture. In rest 25 patients (50\%) in whom plain catgut was used as a skin suture, $1(4 \%)$ patient had mismatch of the colour 1 (4\%) patient had firm texture, 2 (8 $\%)$ patients had the redness of the scar, $2(8 \%)$ patients had serosanguinous collection and 1 (4\%) patient had oedema. None of the patient had frank pus and hypertrophic scar was seen in one patient.

\begin{tabular}{|c|c|c|c|}
\hline $\begin{array}{l}\text { Cosmetic Assessment of } \\
\text { Scar \& Complications }\end{array}$ & $\begin{array}{l}\text { Nylon } \\
\text { n (\%) }\end{array}$ & $\begin{array}{l}\text { Catgut } \\
\text { n (\%) }\end{array}$ & $\begin{array}{c}\text { Statistical } \\
\text { Outcome } \\
\text { P-Value }\end{array}$ \\
\hline \multicolumn{4}{|l|}{ Colour } \\
\hline Perfect & $21(84.0)$ & $24(96.0)$ & 0.349 \\
\hline Mismatch & $4(16.0)$ & $14.0)$ & \\
\hline \multicolumn{4}{|l|}{ Texture } \\
\hline Smooth & $25(100.0)$ & $24(96.0)$ & 1.000 \\
\hline Firm & $0(0)$ & $1(4.0)$ & \\
\hline Redness & $3(12.0)$ & $2(8.0)$ & 0.637 \\
\hline Serosanguinous Collection & $2(8.0)$ & $2(8.0)$ & 1.000 \\
\hline Frank Pus & $0(0)$ & $0(0)$ & ----- \\
\hline Hypertrophic Scar & $0(0)$ & $1(4.0)$ & 1.000 \\
\hline Oedema & $3(12.0)$ & $0(0)$ & 0.235 \\
\hline \multicolumn{4}{|c|}{ Table 1. During $7^{\text {th }}$ Post-Operative Day Follow Up } \\
\hline
\end{tabular}

On $3^{\text {rd }}$ Month follow up, patients with nylon as skin suture, $4(16 \%)$ patients had mismatch of the colour of the scar, 1 (4\%) patient had firm texture and rest all had smooth texture. Redness was seen in 3 (12\%) patients, Serosanguinous discharge was seen in $2(8 \%)$ patients. None of the patient had frank pus, $2(8 \%)$ patients had oedema of the scar, with 1 (4 $\%)$ patient showing hypertrophic scar. The patients sutured with plain catgut on $3^{\text {rd }}$ month showed $1(4 \%)$ patient with mismatch of the colour, 2 (8\%) patients had firm texture, 1 (4\%) patient had redness and frank pus, 2 (8\%) patients showed serosanguinous collection, 2 (8\%) patients had hypertrophic scar.

\begin{tabular}{|c|c|c|c|}
\hline $\begin{array}{l}\text { Cosmetic Assessment of } \\
\text { Scar \& Complications }\end{array}$ & $\begin{array}{l}\text { Nylon } \\
\text { n (\%) }\end{array}$ & $\begin{array}{l}\text { Catgut } \\
\text { n (\%) }\end{array}$ & $\begin{array}{l}\text { Statistical } \\
\text { Outcome } \\
\text { P - Value }\end{array}$ \\
\hline \multicolumn{4}{|l|}{ Colour } \\
\hline Perfect & $21(84.0)$ & $24(96.0)$ & 0.349 \\
\hline Mismatch & $4(16.0)$ & $1(4.0)$ & \\
\hline \multicolumn{4}{|l|}{ Texture } \\
\hline Smooth & $24(96.0)$ & $23(92.0)$ & 0.552 \\
\hline Firm & $1(4.0)$ & $2(8.0)$ & \\
\hline Redness & $3(12.0)$ & $1(4.0)$ & 0.297 \\
\hline Serosanguinous Collection & $2(8.0)$ & $2(8.0)$ & 1.000 \\
\hline Frank Pus & $0(0)$ & $1(4.0)$ & 1.000 \\
\hline Hypertrophic Scar & $1(4.0)$ & $2(8.0)$ & 0.552 \\
\hline Oedema & $2(8.0)$ & $1(4.0)$ & 0.552 \\
\hline \multicolumn{4}{|c|}{ Table 2. During $3^{\text {rd }}$ Month Follow Up } \\
\hline
\end{tabular}

On $8^{\text {th }}$ Month follow up, patients with the nylon skin suture had mismatch of the colour of the scar in $3(12 \%)$ patients, firm texture was seen in 2 (8\%) patients, hypertrophic scar was seen in $2(8 \%)$ patients. In catgut skin suture patients, 3 (12\%) patients had mismatch of the colour of the scar, 2 (8\%) patients had firm texture, $1(4 \%)$ patient showed both redness and frank pus. None of the patient had hypertrophic scar or oedema. Unraveled Plain Catgut Sutures were seen in 5 (20\%) patients.

\begin{tabular}{|cccc|}
\hline $\begin{array}{c}\text { Cosmetic Assessment of } \\
\text { Scar \& Complications }\end{array}$ & $\begin{array}{c}\text { Nylon } \\
\mathbf{n}(\%)\end{array}$ & Catgut & $\begin{array}{c}\text { Statistical } \\
\text { Outcome } \\
\text { P - Value }\end{array}$ \\
Colour & $22(88.0)$ & $22(88.0)$ & 1.000 \\
Perfect & $3(12.0)$ & $3(12.0)$ & \\
Mismatch & $23(92.0)$ & $23(92.0)$ & 1.000 \\
Texture & $2(8.0)$ & $2(8.0)$ & 0.297 \\
Smooth & $1(4.0)$ & $1(4.0)$ & ---- \\
Firm & $0(0)$ & $0(0)$ & 1.000 \\
Redness & $0(0)$ & $1(4.0)$ & 0.490 \\
Serosanguinous Collection & $2(8.0)$ & $0(0)$ & ----- \\
\hline Frank Pus & $0(0)$ & $0(0)$ & \\
Hypertrophic Scar & Table 3. During $\boldsymbol{8}^{\text {th }}$ Month Follow $\boldsymbol{U p}$ \\
\hline Oedema & &
\end{tabular}

\section{DISCUSSION}

The present study comparing absorbable suture Plain catgut with Non-absorbable Nylon suture material was done in paediatric age group between 0 to 10 years. M: F ratio was 3 : 1 in the study done by Karounis et al,10 number of females outnumbered males. In our study 56 percent of patients had history of fall comparable to this study. The cosmetic outcome results of our study were also consistent with previously published reports evaluating the use of absorbable sutures in laceration repair. Holger et al, ${ }^{11}$ using VAS scores, compared the cosmetic outcomes at 9 to 12 months of adult and paediatric patients with facial lacerations repaired using nylon, FAC, and octyl cyanoacrylate. Their results also showed no clinically important differences in VAS scores between the 3 groups. Karounis et $\mathrm{al}^{10}$ also did not detect any clinical difference in cosmetic scores between plain catgut versus nylon sutures in paediatric lacerations at 4 to 5 months. Rates of infection and dehiscence between the two groups were comparable, with infection rate 0 vs 2 with $p=0.3$, and wound dehiscence $2 \%$ vs $11 \%$ with $\mathrm{p}=0.07$. The two study group had similar gender distribution in contrast to our study where male outnumbered females. Lubitz and Coyne ${ }^{12}$ did not detect any difference in cosmetic outcomes between FAC and nonabsorbable sutures at 4 to 12 months. In our study Complication rates were similar in both the group, similar results were seen by Start et al, 13 where a total of 100 children were studied, 50 had chronic catgut skin suture and 50 repaired with silk. In our study there was no significant difference in both groups of number of hypertrophic scars. Similar results were seen with studies done by Helen et al and H. Choudhary et al,14 who concluded that the absorbable sutures designed to degrade rapidly led to lesser scar formation. In our study we had hypertrophic scar in two patients treated with Nylon, similar results were seen by Raemma et $\mathrm{al}^{15}$ in their study where one patient had keloid at $3^{\text {rd }}$ month follow up. For those patients in whom Plain Catgut skin sutures were applied in our study, the sutures that were 
still intact or unraveled were removed at $5^{\text {th }}$ post - operative day. Out of 25 patients, 17 (68\%) had at least one suture remaining on $5^{\text {th }}$ post-operative day which was removed. Present finding is comparable to study done by Raemma et al $^{15}$ where out of 23 patients 16 patients (70\%) had one suture which needed removal. Only two patients in the Catgut group had premature unraveling of the suture comparable with study done by Raemma et al. ${ }^{15}$

\section{CONCLUSIONS}

Absorbable sutures are acceptable alternatives to nonabsorbable sutures in paediatric facial trauma as there are no long-term differences in cosmetic outcome and complication rates between the two sutures.

Financial or Other Competing Interests: None.

\section{REFERENCES}

[1] Beausang E, Floyd H, Dunn KW, et al. A new quantitative scale for clinical scar assessment. Plast Reconstr Surg 1988;102(6):1954-61.

[2] Meszaros L. The right stuff: a primer in closing of wounds. Dermatology Times 2002;23(4):48.

[3] LaBagnara J. A review of absorbable suture materials in head and neck surgery and introduction of monocryl: a new absorbable suture. Ear Nose Throat J 1995;74(6):409-15.

[4] Canarelli JP, Richard J, Collet LM, et al. Use of fast absorbing material for skin closure in young adults. Int Surg 1988;73(3):151-2.
[5] Bruns TB, Simon HK, McLario DJ, et al. Lacerations repair using a tissue adhesives in a children's emergency department. Paediatrics 1996;98(4 Pt 1):673-5.

[6] Mattick A, Clegg G, Beattie T, et al. A randomized, controlled trial comparing a tissue adhesive (2octylcyanoacrylate) with adhesive strips (steristrips) for paediatric laceration repair. Emerg Med J 2002;19(5):405-7.

[7] Christopher JA, Whitaker DC, O'Donnel MJ. Cutaneous surgery ilustrated and practical approach. Ist edn. New York: McGraw Hill 1982;15-26.

[8] Guyuron B, Vaughan C. A comparison of absorbable and nonabsorbable suture materials for skin repair. Plats Reconstr Surg 1992;89(2):234-6.

[9] Grisham JE, Zukin DD. Suture selection for the paediatrician. Paediatr Emerg Care 1990;6(4):301-4.

[10] Karounis H, Gouin S, Eisman H, et al. A randomized controlled trial comparing long-term cosmetic outcomes of traumatic paediatric lacerations repaired with absorbable plain gut versus nonabsorbable nylon sutures. Acad Emerg Med 2004;11(7):730-5.

[11] Holger JS, Wandersee SC, Hale DB. Cosmetic outcomes in facial laceration required with tissue-adhesive, absorbable, and nonabsorbable sutures. Am J Emerg Med 2004;22(4):254-7.

[12] Lubitz D, Coyne C, Windle B. Use of fast absorbable sutures for the repair of paediatric facial lacerations. Arch Paediatr Adolesc Med 1944;148(Suppl):42-3.

[13] Start NJ, Armstrong AM, Robson NJ. The use of chromic catgut in the primary closure of scalo wounds in children. Arch Emerg Med 1989;6(3):216-9.

[14] Choudhary S, Cadier MA. Cleft lip repair: rub off the sutures, not the smile. Plast Reconstr Surg 2000;5(4):1566.

[15] Luck RP, Flood R, Eyal D, et al. Cosmetic outcomes of absorbable versus nonabsorbable sutures in paediatric facial lacerations. Paediatr Emerg Care 2008;24(3):13742. 